\title{
PENGARUH EKUITAS MEREK DAN PROMOSI PENJUALAN TERHADAP LOYALITAS PELANGGAN DIMEDIASI KEPUTUSAN PEMBELIAN
}

\author{
Diansyah \\ Program Studi Manajemen Universitas 17 Agustus 1945 Jakarta \\ Email: diansyah.170845@yahoo.com \\ Rachmat Meidian Putera \\ Program Studi Manajemen Universitas 17 Agustus 1945 Jakarta \\ Email: rachmatmedian.putera@gmail.com
}

\begin{abstract}
Abstrak
Penelitian ini bertujuan tentang pengaruh ekuitas merek dan promosi penjualan terhadap loyalitas pelanggan di mediasi keputusan pembelian pada pengguna operator seluler Telkomsel di kalangan mahasiswa UTA'45 Jakarta. Metode pengambilan sampel dengan teknik non-probability sampling sebanyak 220 orang. Metode analisis data menggunakan Structural Equation Modeling-Partial Least Square (SEM-PLS) dengan menggunakan software Smart PLS versi 3. Tahapan perhitungan PLS menggunakan 2 model yaitu Pengukuran Model (Outer Model) dan Pengujian Model Struktural (Inner Model). Hasil penelitian ini yakni ekuitas merek mempunyai pengaruh positif dan signifikan terhadap loyalitas pelanggan, promosi penjualan tidak mempunyai pengaruh terhadap loyalitas pelanggan, keputusan pembelian mempunyai pengaruh terhadap loyalitas pelanggan secara positif dan signifikan, ekuitas merek tidak mempunyai pengaruh terhadap keputusan pembelian, promosi penjualan mempunyai pengaruh terhadap keputusan pembelian secara positif dan signifikan, ekuitas merek tidak mempunyai pengaruh terhadap loyalitas pelanggan melalui keputusan pembelian, promosi penjualan mempunyai pengaruh positif dan signifikan terhadap loyalitas pelanggan melalui keputusan pembelian.
\end{abstract}

Kata Kunci: Ekuitas Merek, Promosi Penjualan, Loyalitas Pelanggan, Keputusan Pembelian

\section{Abstract}

The aim of this study on the Influence of brand equity and sales promotion on customer loyalty in the mediation purchase decision in the user cellular operator Telkomsel in among university students 17 August 1945 Jakarta. The sampling method by using nonprobability sampling of 220 people. Methods of data analysis using Structural Equation Modeling-Partial Least Square (PLS-SEM) with software version 3. Stages Smart PLS calculation using the two models namely Measurement Model (Outer Model) and Testing Structural Model (Inner Model). The results of this study the brand equity have an influence positively and significantly related to customer loyalty, sales promotion does not have any impact on customer loyalty, purchase decision have an influence on customer loyalty in a positive and significant, brand equity has no effect on customer purchase decision, sales promotion has the effect to purchase decision positively and significantly, brand equity has no effect on customer loyalty through purchase decision, sales promotion has a positive and significant impact on customer loyalty through purchase decision

Keywords: Brand Equity, Sales Promotion, Customer Loyalty, Purchase Decision. 


\section{PENDAHULUAN}

Perkembangan bisnis telekomunikasi saat ini membuat operator seluler di Indonesia berlomba-lomba dalam menarik konsumen untuk melakukan pembelian terhadap produk masing- masing. Keadaan tersebut membuat perusahaan berusaha untuk mempertahankan posisi masingmasing dengan meningkatkan layanan konsumen agar bisa bersaing. Operator seluler yang dapat lebih menggungguli persaingan dapat ditinjau dari tingginya pangsa pasar. Tabel 1 merupakan data pangsa pasar operator seluler GSM dan CDMA di Indonesia.

Namun hal tersebut berbeda di kalangan mahasiswa yang menggunakan operator seluler seperti di Universitas 17 Agustus 1945 Jakarta. Data pada grafik di Gambar 1 menunjukkan bahwa persentase pengguna operator seluler yang paling banyak digunakan adalah Indosat sebesar $32 \%$. Sedangkan persentase pengguna operator seluler lain adalah Telkomsel 26 $\%$, XL $24 \%$, Three $10 \%$, dan CDMA 8\%.

Dari data tersebut menjadi informasi bahwa pengguna operator seluler Telkomsel di kalangan mahasiswa khususnya UTA'45 Jakarta belum memberikan dampak besar pada loyalitas pelanggan. Oleh karena itu dilakukan upaya dengan ekuitas merek dan promosi penjualan.
Strategi-strategi tersebut pada dasarnya bertujuan untuk membangun loyalitas konsumen. Pelanggan yang loyal dapat dilakukan dengan berbagai cara, salah satunya dengan loyalitas pelanggan melalui merek yang terkenal. Keberadaan konsumen yang loyal pada merek sangat diperlukan karena membangun rasa percaya dan memudahkan bagi pelanggan terhadap merek produk tersebut.

Berdasarkan uraian di atas, maka penulis merumuskan masalah sebagai berikut:

1. Bagaimana pengaruh ekuitas merek terhadap loyalitas pelanggan?

2. Bagaimana pengaruhpromosi penjualan terhadap loyalitas pelanggan?

3. Bagaimana pengaruh ekuitas merek terhadap keputusan pembelian?

4. Bagaimana pengaruh promosi penjualan terhadap keputusan pembelian?

5. Bagaimana pengaruh keputusan pembelian terhadap loyalitas pelanggan?

6. Bagaimana pengaruh ekuitas merek terhadap loyalitas pelanggan di mediasi keputusan pembelian?

7. Bagaimana pengaruh promosi penjualan terhadap loyalitas pelanggan di mediasi keputusan pembelian?

Tabel 1. Pangsa Pasar Operator Seluler di Indonesia Tahun 2011-2015

\begin{tabular}{|c|c|c|c|c|c|c|}
\hline & Tahun & 2011 & 2012 & 2013 & 2014 & 2015 \\
\hline Perr & Pasar (Jutaan Unit) & 222,21 & 275,13 & 300,99 & 319,48 & 346,45 \\
\hline \multirow[t]{2}{*}{ Telkomsel } & $\begin{array}{l}\text { Volume Penjualan } \\
\text { (Jutaan Unit) }\end{array}$ & 107,01 & 125,14 & 131,51 & 140,58 & 152,46 \\
\hline & Market Share & $48,10 \%$ & $45,50 \%$ & $45,00 \%$ & $44,00 \%$ & $44,00 \%$ \\
\hline \multirow[t]{2}{*}{ Indosat } & $\begin{array}{l}\text { Volume Penjualan } \\
\text { (Jutaan Unit) }\end{array}$ & 47,90 & 59,68 & 61,37 & 59,74 & 72,76 \\
\hline & Market Share & $21,55 \%$ & $21,70 \%$ & $21,00 \%$ & $18,70 \%$ & $21,00 \%$ \\
\hline \multirow{2}{*}{$\begin{array}{l}\text { XL- } \\
\text { Axiata }\end{array}$} & $\begin{array}{l}\text { Volume Penjualan } \\
\text { (Jutaan Unit) }\end{array}$ & 40,80 & 51,98 & 55,52 & 63,9 & 55,4 \\
\hline & Market Share & $18,40 \%$ & $18,90 \%$ & $19,00 \%$ & $20,00 \%$ & $16,00 \%$ \\
\hline \multirow[t]{2}{*}{ Three } & $\begin{array}{l}\text { Volume Penjualan } \\
\text { (Jutaan Unit) }\end{array}$ & 15,90 & 22,93 & 20,45 & 20,12 & 38,11 \\
\hline & Market Share & $7,17 \%$ & $8,34 \%$ & $7,00 \%$ & $6,30 \%$ & $11,00 \%$ \\
\hline \multirow[t]{2}{*}{ CDMA } & $\begin{array}{l}\text { Volume Penjualan } \\
\text { (Jutaan Unit) }\end{array}$ & 10,60 & 15,4 & 32,14 & 35,14 & 27,72 \\
\hline & Market Share & $4,78 \%$ & $5,56 \%$ & $11,00 \%$ & $11,00 \%$ & $8,00 \%$ \\
\hline
\end{tabular}

Sumber : Bursa Efek Indonesia (BEI) dan data diolah kembali (2016) 


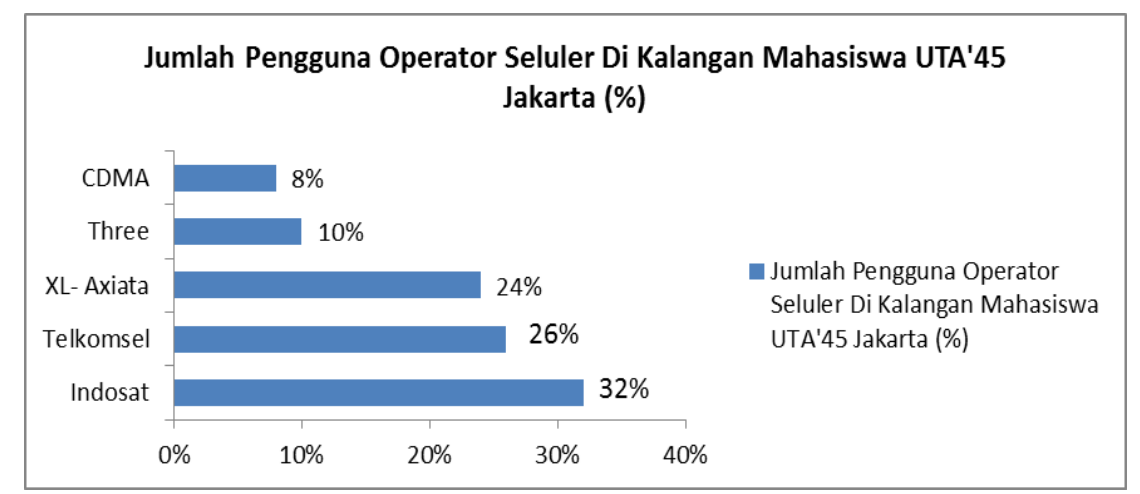

Sumber: Olahan Data (2016)

Gambar 1. Pengguna Operator Seluler 2016

KAJIAN PUSTAKA DAN HIPOTESIS

\section{Loyalitas Pelanggan}

Loyalitas pelanggan sangat penting bagi perusahaan baik produk maupun jasa untuk meningkatkan keuntungan bagi suatu perusahaan, karena apabila pelanggan tidak loyal terhadap produk dari perusahaan tersebut, maka besar kemungkinan pelanggan akan berpaling ke produk lain, dan untuk itu perlu mempertahankan loyalitas pelanggan.

Menurut Griffin (2011:24), mengemukakan bahwa loyalitas pelanggan adalah suatu ukuran yang dapat diandalkan dalam memprediksi pertumbuhan kegiatan penjualan dan segi keuangan, dibandingkan dengan kepuasan pelanggan.

Menurut Kotler dan Keller (2006), indikator loyalitas pelanggan yang digunakan terdiri dari:

a. Repeat Purchase (kesetiaan terhadap pembelian produk). Konsumen yang memiliki ikatan emosional dengan merek produk.

b. Retention (Ketahanan terhadap pengaruh yang negatif mengenai perusahaan). Konsumen yang melakukan pemakaian kembali produk tersebut secara rutin.

c. Referalls (mereferensikan secara total eksistensi perusahaan). Konsumen telah melakukan komunikasi dari mulut ke muluti produk tersebut kepada orang lain.

\section{Ekuitas Merek}

Menurut Surachman (2008), brand equity is the total accumulated value or worth of brand the tangible and intangible asset that the brand contributes to its corporate parent, both financially and interest of selling leverage. Ekuitas merek diartikan sebagai total keseluruhan nilai dan manfaat dari sebuah merek yang yang memberikan kontribusi untuk perusahaan induk, keduanya keuangan dan perhatian memberikan pengaruh.

Menurut Kotler dan Keller (2009; 267) indikator ekuitas merek yang digunakan terdiri dari:

1. Keutamaan merek

Seberapa sering dan seberapa mudah pelanggan memikirkan merek dalam berbagai situasi atau konsumsi.

2. Kinerja merek

Seberapa baik produk atau jasa memenuhi kebutuhan fungsional pelanggan.

3. Pencitraan merek

Berfokus pada pendapat dan evaluasi pribadi pelanggan sendiri.

4. Perasaan merek

Respon dan reaksi emosional pelanggan terhadap merek.

5. Resonansi merek

Mengacu pada hubungan yang dimiliki pelanggan dengan merek dan sejauh mana mereka "sinkron" dengan merek.

\section{Promosi Penjualan}

Menurut Tjiptono dan Chandra (2012:367) mengatakan promosi penjualan adalah segala bentuk penawaran dan insentif jangka pendek yang ditujukan untukpembeli, pengecer atau pedagang grosir dan dirancang untuk memperoleh respon spesifik. 
Selain memperhatikan alat-alat promosi penjualan perusahaan harus bisa memilih indikator-indikator promosi penjualan yang tepat dalam memproduksikan produk. Menurut Kotler dan Keller (2007: 202) diantaranya antara lain:

1. Frekuensi Promosi adalah jumlah promosi penjualan yang dilakukan dalam suatu waktu melalui media promosi penjualan.

2. Kualitas Promosi adalah sebuah tolok ukur seberapa baik promosi penjualan yang telah dilakukan.

3. Kuantitas Promosi adalah nilai atau jumlah promosi penjualan yang diberikan konsumen.

4. Waktu promosi adalah lamanya promosi yang dilakukan oleh perusahaan.

5. Ketetapan atau kesesuaian sasaran promosi merupakan faktor yang diperlukan untuk mencapai target yang diinginkan perusahaan.

\section{Keputusan Pembelian}

Menurut Assauri (2010:141), keputusan pembelian adalah proses yang mencakup penentuan apa yang akan dibeli atau tidak melakukan pembelian dan keputusan itu diperoleh dari kegiatankegiatan sebelumnya.

Menurut Kotler dan Keller (2005: 202) indikator keputusan pembelian terdiri dari:

1. Pilihan produk

Konsumen dapat mengambil keputusan untuk membeli produk atau menggunakan uangnya untuk tujuan lain.

2. Pilihan merek

Konsumen harus memutuskan merek mana yang akan dibeli.

3. Pilihan pemasok atau penyalur

Konsumen harus memutuskan penyalur mana yang akan dikunjungi.

4. Jumlah pembelian

Konsumen dapat mengambil keputusan seberapa banyak produk yang akan dibeli konsumen
5. Frekuensi pembelian

Keputusan konsumen dalam memilih seberapa sering dia membeli suatu produk dan waktu yang tepat dalam membeli dapat berbeda-beda.

6. Metode pembayaran

Konsumen harus mengambil keputusan tentang metode pembayaran pada produk yang dibeli, apakah nanti secara tunai atau cicilan.

\section{Pengaruh Ekuitas Merek terhadap Loyalitas Pelanggan}

Konsumen yang menunjukan sikap positifnya oleh suatu merek dan mempunyai komitmen pada merek tertentu atau berniat untuk terus membelinya menunjukan kepuasan dan kesetiaan terhadap merek tersebut. Dari kepuasan dan kesetiaan konsumen terhadap merek akan terbentuk loyalitas.

Hal ini sama dengan penelitian terdahulu menurut Soraya dan Hermawan (2013), Hadi (2015), Filho et al., (2010), dan Ivanauskiene dan Volungenaite (2015) menyatakan bahwa ekuitas merek memiliki pengaruh terhadap loyalitas pelanggan secara positif dan signifikan. Berdasarkan penelitian tersebut dapat dibentuk $\mathrm{H} 1$ : ekuitas merek berpengaruh terhadap loyalitas pelanggan.

\section{Pengaruh Promosi Penjualan terhadap Loyalitas Pelanggan}

Promosi penjualan yang dilakukan dengan pemberian hadiah langsung, undian, dan gift kepada pelanggan telah dilaksanakan dengan cukup baik dan adil, hal ini memberikan arti bahwa promosi penjualan memberikan pengaruh akan tercipta loyalitas nasabah yang tinggi sehingga pelanggan tidak ingin berpindah ke perusahaan lain.

Hal ini sesuai dengan penelitian terdahulu menurut Dezilet al.,(2011), Astuti et al., (2014), Omotayo (2011), dan Kabouh et al.,(2016) menyatakan bahwa promosi penjualan mempunyai pengaruh terhadap loyalitas pelanggan secara positif dan signifikan. Berdasarkan penelitian 
tersebut dapat dibentuk $\mathrm{H} 2$ : promosi penjualan berpengaruh terhadap loyalitas pelanggan.

\section{Pengaruh Ekuitas Merek terhadap Keputusan Pembelian}

Merek memiliki pengaruh yang tinggi dalam hal keputusan pembelian, sebagai identitas dari suatu perusahaan, dan merupakan pembeda dari produk satu dengan yang lain. Merek merupakan simbol atau logo yang dapat membangun persepsi konsumen terhadap suatu produk. Ekuitas merek akan memberikan alasan kepada para konsumennya untuk melakukan pembelian dengan berbagai pertimbangannya.

Hal ini sesuai dengan penelitian terdahulu menurut Pradipta et al., (2016), Pandensolang dan Tawas (2015), Akhtar et al., (2016), dan Doostar et al.,(2012) menyatakan bahwa ekuitas merek memiliki pengaruh terhadap keputusan pembelian secara positif dan signifikan. Berdasarkan penelitian tersebut dapat dibentuk H3: ekuitas merek berpengaruh terhadap keputusan pembelian.

\section{Pengaruh Promosi Penjualan terhadap Keputusan Pembelian}

Promosi penjualan menjadi pertimbangan yang sangat penting bagi pelanggan dalam menentukkan keputusan pembelian. Hal ini menunjukkan bahwa promosi penjualan yang menarik akan mampu mempengaruhi seseorang untuk melakukan pembelian.

Menurut Mariana dan Saino (2015), Wahyuni et al., (2016), Neha dan Manoj (2013), dan Chakrabortty et al., (2012) menyatakan promosi penjualan mempunyai pengaruh terhadap keputusan pembelian secara positif dan signifikan. Berdasarkan penelitian tersebut dapat dibentuk H4: promosi penjualan berpengaruh terhadap keputusan pembelian.

\section{Pengaruh Keputusan Pembelian ter- hadap Loyalitas Pelanggan}

Melakukan pembelian suatu produk dan mampu memberikan nilai lebih memungkinkan pelanggan mendukung produk yang disukai dimana akan mempengaruhi loyalitas pelanggan.

Menurut Rejeki et al., (2015), Anjani et al., (2015), Susanto (2013), dan Lee (2016) bahwa keputusan pembelian mempunyai pengaruh terhadap loyalitas pelanggan secara positif dan signifikan. Berdasarkan penelitian tersebut dapat dibentuk H5: keputusan pembelian berpengaruh terhadap loyalitas pelanggan.

\section{Pengaruh Ekuitas Merek terhadap Loyalitas Pelanggan di mediasi Kepu- tusan Pembelian}

Semakin kuatnya ekuitas merek suatu produk, semakin kuat pula daya tariknya di mata konsumen untuk mengkonsumsi produk tersebut yang selanjutnya akan membawa konsumen untuk melakukan pembelian secara berulang-ulang sehingga menimbulkan loyalitas pelanggan.

Menurut Suharyono et al., (2013), Marchal et al., (2015), Leone et al., (2010), dan Kumar et al., (2016) menyatakan bahwa ekuitas merek terhadap loyalitas pelanggan secara positif dan signifikan. Dan ekuitas merek terhadap keputusan pembelian secara positif dan signifikan. Berdasarkan uraian di atas dapat dibentuk hipotesis H6: ekuitas merek berpengaruh terhadap loyalitas pelanggan di mediasi keputusan pembelian.

\section{Pengaruh Promosi Penjualan terhadap Loyalitas Pelanggan di mediasi Kepu- tusan Pembelian}

Menurut Yuliana dan Ika (2015), Saeed et al., (2013), dan Shrestha (2015) menyatakan bahwa promosi penjualan mempunyai pengaruh terhadap loyalitas pelanggan positif dan signifikan. Dan promosi penjualan mempunyai pengaruh terhadap keputusan pembelian positif dan signifikan. Berdasarkan uraian di atas dapat dibentuk hipotesis $\mathrm{H} 7$ : promosi penjualan berpengaruh terhadap loyalitas 
pelanggan di mediasi keputusan pembelian.

\section{METODE PENELITIAN}

Menurut Sukmadinata (2011: 250) mengemukakan populasi merupakan sekumpulan dan wilayah yang menjadi ruang lingkup penelitian. Populasi adalah keseluruhan objek yang akan/ ingin diteliti. Anggota populasi dapat berupa benda hidup maupun benda mati dimana sifatsifat yang ada padanya dapat diamati dan diukur. Populasi penelitian adalah mahasiswa UTA'45 Jakarta sebanyak 553 mahasiswa.

Teknik penentuan sampel yang akan digunakan adalah teknik purposive sampling. Teknik purposive sampling adalah teknik penentuan sampel berdasarkan kriteria tertentu. Sampel yang diperoleh dalam lingkup penelitian sebesar 220 responden.

Metode Pengambilan sampel pada penelitian ini menggunakan metode purposive sampling terhadap pengguna operator telkomsel di UTA'45, Jakarta. Teknik purposive sampling adalah teknik yang dilakukan berdasarkan kriteria tertentu. Adapun kriteria yang dijadikan sampel adalah:

1. Semua pengguna operator seluler Telkomsel di kalangan mahasiswa UTA'45, Jakarta.

2. Semua pelanggan yang sudah menggunakan kartu seluler telkomsel pada tahun 2016 (periode waktu awal November-akhir Desember 2016).

3. Penggunaan kartu seluler operator lainnya bersamaan Telkomsel.

4. Berdasarkan kriteria pengambilan sampel sebesar 220 responden.

\section{ANALISIS DAN PEMBAHASAN Uji Validitas}

Berdasarkan hasil perhitungan dengan menggunakan PLS diketahui Outer Model seperti pada Gambar 2. Berdasarkan gambar tersebut dapat dilihat dari masingmasing variabel ekuitas merek (X1), promosi penjualan (X2), loyalitas pelanggan (Y), dan keputusan pembelian (Z). Nilai loading factor-nya adalah indikator ekuitas merek (X1P1) sebesar 0,848, indikator promosi penjualan (X2P1) sebesar 0,520, indikator loyalitas pelanggan (YP1) sebesar 0,785, dan indikator keputusan pembelian (ZP1) sebesar 0,642. Karena masing-masing variabel nilai loading factor-nya di atas 0,5 maka dapat dikatakan semua variabel valid.

\section{Uji Reliabilitas}

Berdasarkan perhitungan dengan menggunakan PLS diketahui hasil Composite Reliability, Cronbach Alpha, Average Variance Extracted seperti pada Tabel 2. Uji kehandalan data dilakukan dengan menggunakan Composite Reliability. Menurut Ghozali (2008), mengatakan bahwa "The unidimensionality of the block of variables may be assessed by using composite reliability (should be > 0,7)". Berdasarkan Tabel 2 dapat dilihat dari masing-masing variabel ekuitas merek (X1), promosi penjualan (X2), loyalitas pelanggan (Y), keputusan pembelian (Z), Quadratic Effect 1, dan Quadratic Effect 2 nilai $\mathrm{CR}$ di atas 0,7 maka dapat dikatakan reliabel.

Cronbach alpha adalah tingkat konsistensi jawaban responden dalam satu variabel laten. Berdasarkan tabel di atas dapat dilihat dari masing-masing variabel ekuitas merek (X1), promosi penjualan (X2), loyalitas pelanggan (Y), keputusan pembelian (Z), Quadratic Effect 1, dan Quadratic Effect 2 nilai CA di atas 0,7 maka dapat dikatakan reliabel.

Untuk mengukur banyaknya varians yang dapat ditangkap oleh konstruknya menggunakan AVE. Nilai AVE harus >0,5. Berdasarkan Tabel 2 dapat dilihat dari masing-masing variabel ekuitas merek (X1), promosi penjualan (X2), loyalitas pelanggan (Y), keputusan pembelian (Z), Quadratic Effect 1, dan Quadratic Effect 2 nilai AVE di atas 0,5, maka dapat dikatakan reliabel. 


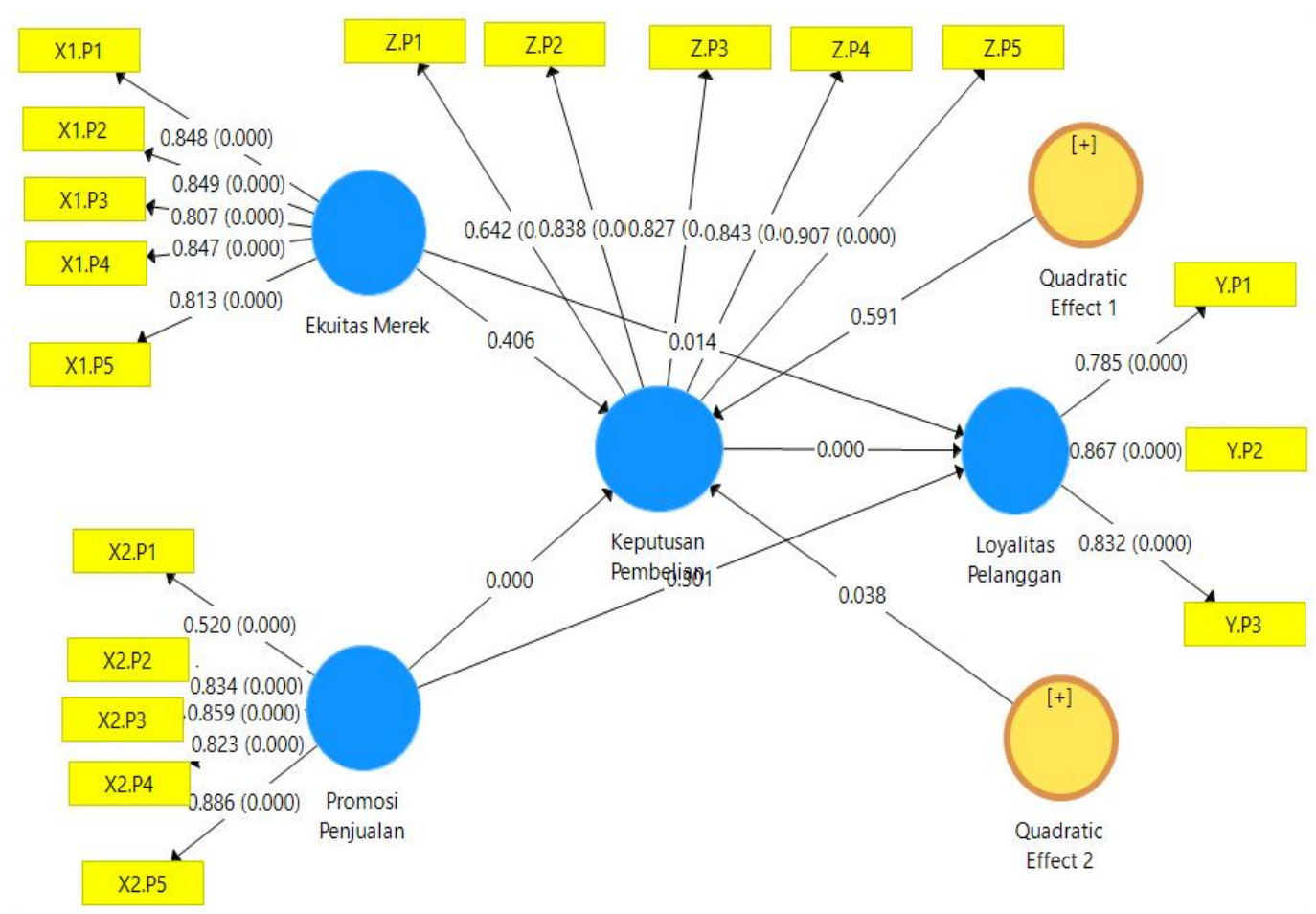

Sumber: Hasil Olah Data SmartPLS (2016)

Gambar 2. Model Pengaruh Ekuitas Merek dan Promosi Penjualan terhadap Loyalitas Pelanggan di Mediasi Keputusan Pembelian

Tabel 2. Hasil Composite Reliability, Cronbach Alpha, Average Veriance Extracted

\begin{tabular}{lccc}
\hline \multicolumn{1}{c}{ Variabel } & $\begin{array}{c}\text { Composite } \\
\text { Reliability }(\text { CR })\end{array}$ & $\begin{array}{c}\text { Cronbach } \\
\text { Alpha }(\text { CA })\end{array}$ & $\begin{array}{c}\text { Average Variance } \\
\text { Extracted }(\text { AVE) }\end{array}$ \\
\hline Quadratic Effect 1 -> Z & 1,000 & 1,000 & 1,000 \\
Quadratic Effect 2 -> Z & 1,000 & 1,000 & 1,000 \\
X1 & 0,919 & 0,890 & 0,694 \\
X2 & 0,893 & 0,847 & 0,635 \\
Y & 0,868 & 0,780 & 0,687 \\
Z & 0,908 & 0,870 & 0,666 \\
\hline
\end{tabular}

Sumber: Hasil Olah Data SmartPLS (2016)

\section{Koefisien Determinasi}

Sesuai dengan model pengukuran pengaruh ekuitas merek dan promosi penjualan terhadap loyalitas penjualan melalui keputusan pembelian dapat dilihat pada Tabel 3.

\section{Tabel 3. Nilai $R$-Square}

\begin{tabular}{ll}
\hline \multicolumn{1}{c}{ Variabel } & R-Square \\
\hline Loyalitas Pelanggan & 0,617 \\
Keputusan Pembelian & 0,759
\end{tabular}

Sumber: Hasil Olah Data SmartPLS (2016)
Berdasarkan Tabel 3 diketahui nilai konstruk loyalitas pelanggan $=0,617$. Hal ini mengandung makna pengaruh ekuitas merek dan promosi penjualan terhadap loyalitas pelanggan sebesar 61,7 \% sedangkan sisanya 38,3 \% dipengaruhi oleh faktor lainnya. Selanjutnya nilai konstruk keputusan pembelian $=0,759$. Hal ini mengandung makna bahwa pengaruh ekuitas merek, promosi penjualan terhadap keputusan pembelian sebesar 75,9\% sedangkan sisanya $24,1 \%$ dipengaruhi oleh faktor lainnya. 


\section{Pembuktian Hipotesis dan Perban- dingan dengan Penelitian Terdahulu}

Selanjutnya untuk mengetahui pembuktian hipotesis dapat dilihat pada nilai path coefficients pada Tabel 4.

Pengujian Hipotesis 1: Pengaruh Ekuitas Merek terhadap Loyalitas Pelanggan

Berdasarkan Tabel 4 menghasilkan nilai original sample $=0,317, T$ Statistic $=$ 2,388 > 1,96 dan $P$ Value $=0,017<0,05$. Hal ini berarti bahwa ekuitas merek mempunyai pengaruh terhadap loyalitas pelanggan secara positif dan signifikan. Dengan demikian sesuai dengan penelitian sebelumnya dari Filho et al., (2010), Soraya dan Hermawan (2013), Ivanauskiene dan Volungenaite (2015) dan Hadi (2015) yang menyatakan ekuitas merek berdampak signifikan terhadap loyalitas pelanggan. Hal ini membuktikan bahwa hipotesis pertama (H1) diterima.

\section{Pengujian Hipotesis 2: Pengaruh Promosi Penjualan terhadap Loyalitas Pelanggan}

Berdasarkan Tabel 4 menghasilkan nilai original sample $=-0,136, T$ Statistic $=$ $1,004<1,96$, dan $P$ Value $=0,316>0,05$. Hal ini berarti bahwa promosi penjualan tidak mempunyai pengaruh terhadap loyalitas pelanggan. Hasil ini tidak sesuai dengan penelitian dari Omotayo (2011), Dezil, et al., (2011), Astuti et al., (2014), dan Kabouh et al.,(2016) yang menyatakan promosi penjualan berpengaruh signifikan terhadap loyalitas pelanggan. Hasil penelitian ini membuktikan bahwa hipotesis kedua (H2) ditolak. Hal ini dikarenakan kurang menariknya promosi yang dilakukan oleh Telkomsel yang menyebabkan loyalitas pelanggan semakin berkurang, dimana promosi yang dilakukan oleh Telkomsel kurang inovatif dan monoton contohnya Telkomsel jarang sekali melakukan event-event yang menarik perhatian pelanggan.
Pengujian Hipotesis 3: Pengaruh Ekuitas Merek terhadap Keputusan Pembelian

Berdasarkan Tabel 4 menghasilkan nilai original sample $=-0,071, T$ Statistic $=$ $0,813<1,96$, dan $P$ Value $=0,416>0,05$. Hal ini berarti bahwa ekuitas merek tidak mempunyai pengaruh terhadap keputusan pembelian. Hasil ini tidak sesuai dengan penelitian sebelumnya dari Doostar et al., (2012), Pandensolang dan Tawas (2015), Pradipta, et al.,(2016) dan Akhtar et al., (2016), yang menyatakan brand equity berpengaruh positif dan signifikan terhadap keputusan pembelian. Hal ini membuktikan bahwa hipotesis ketiga (H3) ditolak. Hal ini dikarenakan terlalu banyak pilihan merek provider jaringan dapat mempengaruhi keputusan pembelian karena hampir setiap provider memberikan pelayanan yang sama sehingga konsumen tidak terpaku pada satu merek tertentu saja.

\section{Pengujian Hipotesis 4: Pengaruh Promosi Penjualan terhadap Keputusan Pembelian}

Berdasarkan Tabel 4 menghasilkan nilai original sample $=0,893, T$ Statistic $=$ $16,639>1,96$, dan $P$ Value $=0,000<0,05$. Hal ini berarti bahwa promosi penjualan mempunyai pengaruh terhadap keputusan pembelian secara positif dan signifikan. Penelitian ini sesuai dengan penelitian dari Chakrabortty et al., (2012) dan Neha dan Manoj (2013), Mariana dan Saino (2015) dan Wahyuni et al., (2016), menyatakan promosi penjualan berpengaruh positif dan signifikan terhadap keputusan pembelian. Hal ini membuktikan bahwa hipotesis keempat (H4) diterima.

\section{Pengujian Hipotesis 5: Pengaruh Keputusan Pembelian Terhadap Loyalitas Pelanggan}

Berdasarkan Tabel 4 menghasilkan nilai original sample $=0,729, T$ Statistic $=$ $5,763>1,96$, dan $P$ Value $=0,000<0,05$. Hal ini berarti bahwa keputusan pembelian mempunyai pengaruh terhadap loyalitas pelanggan secara positif dan signifikan. 
Dengan demikian penelitian ini sesuai dengan penelitian sebelumnya dari Susanto (2013), Rejeki, et al.,(2015), Anjani et al., (2015), dan Lee (2016) yang menyatakan keputusan pembelian berpengaruh positif dan signifikan terhadap loyalitas pelanggan. Hal ini membuktikan bahwa hipotesis kelima (H5) diterima.

\section{Pengujian Hipotesis 6: Pengaruh Ekuitas Merek terhadap Loyalitas Pelanggan di mediasi Keputusan Pembelian}

Berdasarkan Tabel 4 menghasilkan nilai original sample $=0,024, T$ Statistic $=$ $0,557<1,96$, dan $P$ Value $=0,578>0,05$. Hal ini berarti bahwa ekuitas merek tidak mempunyai pengaruh terhadap loyalitas pelanggan melalui keputusan pembelian. Hasil penelitian ini tidak sesuai dengan penelitian sebelumnya dari Suharyono et al., (2013), Marchal et al., (2015), Leone et al., (2010), dan Kumar et al., (2016) menyatakan bahwa ekuitas merek terhadap loyalitas pelanggan secara positif dan signifikan. Ekuitas merek terhadap keputusan pembelian secara positif dan signifikan. Hal ini membuktikan bahwa hipotesis keenam (H6) ditolak. Hal ini dikarenakan terlalu banyaknya pilihan merek provider jaringan dapat mempengaruhi loyalitas pelanggan melalui keputusan pembelian sehingga berdampak kuat karena hampir setiap provider memberikan pelayanan yang sama sehingga konsumen tidak terpaku pada satu merek tertentu. Dengan demikian keputusan pembelian tidak dapat dijadikan variable mediasi (variabel intervening)

\section{Pengujian Hipotesis 7: Pengaruh Promosi Penjualan terhadap Loyalitas Pelanggan di mediasi Keputusan Pembelian}

Berdasarkan Tabel 4 menghasilkan nilai original sample $=0,116, T$ Statistic $=$ $2,065>1,96$, dan $P$ Value $=0,039<0,05$. Hal ini berarti bahwa promosi penjualan mempunyai pengaruh terhadap loyalitas pelanggan melalui keputusan pembelian secara positif dan signifikan. Hasil ini sesuai dengan penelitian sebelumnya dari Saeed et al., (2013), Yuliana dan Ika (2015), dan Shrestha (2015) menyatakan bahwa promosi penjualan mempunyai pengaruh terhadap loyalitas pelanggan positif dan signifikan. Promosi penjualan mempunyai pengaruh terhadap keputusan pembelian positif dan signifikan. Hal ini membuktikan bahwa hipotesis ketujuh (H7) diterima.

Tabel 4. Nilai Path Coefficients

\begin{tabular}{lccccc}
\hline \multicolumn{1}{c}{ Variabel } & $\begin{array}{c}\text { Original } \\
\text { Sample }(\boldsymbol{O})\end{array}$ & $\begin{array}{c}\text { Sample } \\
\text { Mean }(\boldsymbol{M})\end{array}$ & $\begin{array}{c}\text { Standard } \\
\text { Deviation }(\text { STDEV) }\end{array}$ & T Statistic & P Value \\
\hline Quadratic Effect $1 \rightarrow \mathrm{Z}$ & 0,024 & 0,029 & 0,044 & 0,557 & 0,578 \\
Quadratic Effect $2 \rightarrow \mathrm{Z}$ & 0,116 & 0,115 & 0,056 & 2,065 & 0,039 \\
$\mathrm{X} 1 \rightarrow \mathrm{Y}$ & 0,317 & 0,340 & 0,133 & 2,388 & 0,017 \\
$\mathrm{X} 1 \rightarrow \mathrm{Z}$ & $-0,071$ & $-0,054$ & 0,088 & 0,813 & 0,416 \\
$\mathrm{X} 2 \rightarrow \mathrm{Y}$ & $-0,136$ & $-0,147$ & 0,138 & 1,004 & 0,316 \\
$\mathrm{X} 2 \rightarrow \mathrm{Z}$ & 0,893 & 0,889 & 0,054 & 16,639 & 0,000 \\
$\mathrm{Z} \rightarrow \mathrm{Y}$ & 0,729 & 0,714 & 0,126 & 5,763 & 0,000 \\
\hline
\end{tabular}

Sumber: Hasil Olah Data SmartPLS (2016)

\section{PENUTUP}

\section{Kesimpulan}

Berikut adalah kesimpulan sekaligus merupakan jawaban dari permasalahan yang ada dalam penelitian ini. Sesuai dengan analisis data yang dilakukan, maka dapat di simpulkan sebagai berikut:
1. Ekuitas merek mempunyai pengaruh terhadap loyalitas pelanggan secara positif dan signifikan. Hal ini dikarenakan suatu merek yang mempunyai level tinggi dapat mempengaruhi loyalitas pelanggan. 
2. Promosi penjualan tidak mempunyai pengaruh terhadap loyalitas pelanggan. Hal ini dikarenakan kurang menarik promosi yang dilakukan oleh Telkomsel yang menyebabkan loyalitas pelanggan. Promosi yang dilakukan oleh Telkomsel kurang inovatif dan monoton contohnya Telkomsel jarang sekali melakukan event-event yang menarik perhatian pelanggan.

3. Ekuitas merek tidak mempunyai pengaruh terhadap keputusan pembelian. Hal ini dikarenakan oleh terlalu banyak pilihan merek provider jaringan dapat mempengaruhi keputusan pembelian karena hampir setiap provider memberikan pelayanan yang sama sehingga konsumen tidak terpaku pada satu merek tertentu.

4. Promosi penjualan mempunyai pengaruh terhadap keputusan pembelian secara positif dan signifikan. Hal ini dikarenakan menariknya promosi yang dilakukan dapat menjadi pilihan konsumen dalam memutuskan pembelian.

5. Keputusan pembelian mempunyai pengaruh terhadap loyalitas pelanggan secara positif dan signifikan. Hal ini dikarenakan konsumen menganggap kinerja dari Telkomsel memuaskan yang mengakibatkan terbentuknya loyalitas.

6. Ekuitas merek tidak mempunyai pengaruh terhadap loyalitas pelanggan melalui keputusan pembelian. Hal ini dikarenakan terlalu banyak pilihan merek provider jaringan dapat mempengaruhi loyalitas pelanggan melalui keputusan pembelian sehingga berdampak kuat karena hampir setiap provider memberikan pelayanan yang sama sehingga konsumen tidak terpaku pada satu merek tertentu.

7. Promosi penjualan mempunyai pengaruh terhadap loyalitas pelanggan di mediasi keputusan pembelian secara positif dan signifikan. Hal ini dikarenakan promosi yang dilakukan Telkomsel seperti acara atau event yang dilakukan dapat memicu keputusan pembelian yang berdampak pada loyalitas.

\section{Saran}

Berdasarkan hasil penelitian, ada beberapa saran yang diajukan peneliti yang dapat digunakan untuk penelitian selanjutnya yaitu:

1. Perusahaan harus lebih meningkatkan ekuitas merek dan promosi penjualan untuk mendapatkan loyalitas pelanggan.

2. Untuk mendukung agar jumlah konsumen lebih meningkat, perusahaan harus lebih kreatif dalam menciptakan strategi-strategi baru dan inovasi baru agar konsumen tidak beralih ke provider lain.

3. Untuk peneliti selanjutnya diharapkan menambah faktor-faktor lain sebagai variabel independen di luar variable yang sudah diteliti

\section{DAFTAR PUSTAKA}

Akhtar, N., Siddiqi, U. I., Ashraf, A., \& Latif, M. (2016). Impact of Brand Equity on Consumer Purchase Decision in L'Oreal Skincare Products. International Review of Management and Business Research, 5(3), 808.

Akkucuk, U., \& Esmaeili, J. (2015). The Impact of Brand Equity on Consumer Purchase Decision An Empirical Study On Smartphone Buyers. Journal of Management, 12(7).

Anjani, G. A., P. Isyanto., \& Muslihat, A. (2015). Pengaruh Positioning dan Keputusan Pembelian terhadap Loyalitas Pelanggan pada AJB Bumiputera. Skripsi. 
Astuti, W. S. S., Wahyuningsih, E., Winarti, E., \& Yatna, C. N. (2014). Pengaruh Atmosfer Toko dan Promosi Penjualan terhadap Loyalitas Pelanggan Centro Department Store Plaza Semanggi. Jurnal Manajemen, 13(04), 1-13.

Boonwanna, P., Srisuwannapa, C., \& Rojniruttikul, N. (2014). The Effect Brand Equity to Purchasing Decision Process of Doughnut from the Department Store in Bangkok. Journal of Marketing Management. 09(8).

Bursa Efek Indonesia. http://www.idx.co.id/. Diakses pada 29 Oktober 2016. (21.00).

Chakrabortty, R. K., Hossain, M., Azad, F. H., \& Islam, J. (2012). Analyzing the Effects of Sales Promotion and Advertising on Consumer Purchase Decision. Journal of Management University Pakistani. 20(3).

Chen, Y. S., J. C. Tso., \& Lin, C. C. (2016). The Analyses of Purchasing Decisions to Customer Loyalty for Smartphone Consumers. Journal of Management. 12(9).

Chitra, D., \& Mahalakshmi, V. (2016). The Effect Sales Promotion on Consumers Purchase Decision Towards Inverter Air Conditioner an Emprical. Journal of Management. 12(4), 23-26.

Dezil, M., Yazri \& Abror. (2011). Pengaruh Kualitas Pelayanan, Promosi Penjualan dan Lokasi terhadap Loyalitas Nasabah. Skripsi.
Doostar, M., M. K. I. Abadi., \& Abadi, R. K. I. (2012). Impact of Brand Equity on Purchase Decision of Final Consumer Focusing on Products with Low Mental Conflict. Journal of Management.09(6).

Filho, C. G., Monteiro, P. R. R., \& Souki, G. Q. (2010). The Impacts of Brand Love, Brand Equity on the Consumer's Loyalty: The Development and Testing of Alternative Models in the Automotive Sector. Journal of Management. 08(45).

Fouladivanda, F., M. A. Pashand., A. Hooman., \& Khanmohammadi, Z. (2012). The effect of Brand Equity on Consumer Purchase Decision in term of FMCG Iran. Journal of Management.11(2).

Gunawardane, N. R. (2015). Impact of Brand Equity towards Purchasing Decision: A Situation on Mobile Telecommunication Services of Sri Lanka. Journal of Marketing Mangement.10(2), 100-117.

Hadi, M. I. (2015). Pengaruh Ekuitas Merek dan Kepuasan Pelanggan Terhadap Loyalitas Pelanggan Smartphone Samsung. Tesis Universitas Muhammadiyah Yogyakarta.

Ivanauskiene, N., \& Volungenaite, J. (2015). The Influence of Brand Equity to Customer Loyalty: An Empirical Investigation of Retail Chain Stores in Emerging Markets. Journal of Management. 01(23). 
Kabuoh, M.N., Odomokwu, R., Ogbuanu, B. K., \& Emmanuel, U. I. (2016). Impact of Sales Promotion on Customers' Loyalty: Case of Cadbury Plc. Journal of Management. 07(3).

Kotler, P. (2006). Manajemen Pemasaran. $11^{\text {th }}$ ed. Indeks. Jakarta: Erlangga.

Kotler, P. \& Keller, K. L. (2012). Marketing Management. $14^{\text {th }}$ ed. United States America: Person Education.

Kotler, P., \& Keller, K. L. (2009). Manajemen Pemasaran. $13^{\text {th }}$ ed. Jakarta: Erlangga.

Kotler, P., \& Keller, K. L. (2005). Marketing Management. United States America: Practice Hall Inc.

Kumar, M. S., Kumar., D. P. \& Narayana, M. S. (2016). Impact of Brand Equity on Customers Purchase Decision Making while Choosing Branded over Unbranded Apparel. Journal of Management.17(12).

Lee, J. H. (2016). A Study on the Impact of Social Commerce Purchase Decision Factors on Customer Loyalty. Journal of Management. 15(17).

Leone, R. P., Rao, V.R., Luo, A. M., McAlister, L. \& Srivastava, R. (2010). Linking Brand equity to Customer Loyalty. Thesis.

Marchall, M., Mananeke, L., \& Roring, F. (2015). Pengaruh Brand Equity, Store Atmosphere dan Sikap Konsumen Terhadap Keputusan Pembelian Pakaian Fashionable. Jurnal Manajemen Universitas Sam Ratulagi. 4(2).
Marina, R. \& Saino. (2015). Pengaruh Kualitas Produk dan Promosi Penjualan terhadap Keputusan Pembelian Indomie Kuliner Nusantara Rasa. Skripsi Universitas Negeri Surabaya.

Neha, S., \& Manoj, V. (2013). Impact of Sales Promotion Tools on Consumer's Purchase Decision towards White Good Refrigerator at Durg and Bhilai Region of CG. Journal of Management. 23(2).

Omotayo, O. (2011). Sales Promotion and Consumer Loyalty: A Study In the of Nigerian Tecommunication Industry. Thesis.

Pandensolang, J. D. \& Tawas, H. N. (2015). Pengaruh Diferensiasi, Kualitas Produk dan Ekuitas Merek Terhadap Keputusan Pembelian COCA-COLA. Jurnal Manajemen Universitas Sam Ratulangi. 14(7).

Pradipta, D., Hidayat, K. \& Sunarti. (2016). Pengaruh Brand Equity terhadap Keputusan Pembelian. Jurnal Administrasi Bisnis Universitas Brawijaya. 2(3).

Rejeki, D. S., Fauzi, A. D. H. \& Yulianto, E. (2015). Pengaruh Green Marketing pada Keputusan Pembelian dan Implikasinya terhadap Loyalitas Pelanggan. Jurnal Administrasi Bisnis. 3(14).

Saeed, R., Nisar, F., Lodhi, R. N., Ahmad, M. \& Arshad, H. M. (2013). Impact of Sales Promotion on the Consumer Loyalty in the Telecommunication Industry. Journal of Management. 07(3). 
Shrestha, A. (2015). Effects of Sales Promotion on Purchasing Decision of Customer A Case Study of Baskin Robbins icecream. Thesis University Bangkok.

Soraya, I., \& Hermawan, E. (2013). Pengaruh Promosi dan Ekuitas Merek terhadap Loyalitas Konsumen Cipaganti. Skripsi.

Suharyono, F. M., \& Hidayat, K. (2013). Pengaruh Ekuitas Merek terhadap Loyalitas Pelanggan. Skripsi.

Susanto, A. H. (2013). The Influence of Customer Purchase Decision on Customer Satisfaction and Customer Loyalty. Thesis Universitas Brawijaya.

Tjiptono, F. \& Chandra, G. (2012). Pemasaran Stratejik. $2^{\text {nd }}$ ed. Yogyakarta: Andi.

Yuliana, I. \& Setiawan, R. (2015). Pengaruh Pelayanan dan Promosi Penjualan terhadap Loyalitas Pelanggan melalui Keputusan Pembelian. Skripsi. 